\title{
A evolução da indústria de máquinas e equipamentos no Brasil: Dedini e Romi, entre 1920 e 1960
}

Palavras-chave

indústria, máquinas e equipamentos, Dedini, Romi

\section{Classificação JEL}

N76, N86, O39

Keywords

industry, machinery and equipment, Dedini, Romi

\section{JEL Classification}

N76, N86, O39

\section{Resumo}

O objetivo do artigo é examinar a evolução do mercado da indústria de máquinas e equipamentos no Brasil e em São Paulo, entre 1920 e 1960 , tendo como objeto de estudo duas empresas importantes para o fortalecimento dessa indústria no país, a Dedini e a Romi. A escolha dessas empresas deve-se à existência de estudos específicos e acervos históricos com documentos econômico-financeiros. Serão destacadas as semelhanças e as diferenças no desempenho dessas duas empresas no contexto da evolução do mercado da indústria de máquinas e equipamentos. Essas surgiram como pequenas oficinas nas primeiras décadas do século XX e evoluíram com o mercado específico em que atuavam, com grandes mudanças nas décadas de 1920 e 1930, e se fortaleceram no setor após a década de 1940. Na década de 1960, eram as principais empresas da indústria em que atuavam.
Michel Deliberali Marson*

\section{Abstract}

The aim of this paper is to examine the evolution of the market machinery industry in Brazil and Sao Paulo between 1920 and 1960 , with the object study of two major companies for consolidation in this industry country, Dedini and Romi. The choice of these companies due to the existence of specific studies and historical collections with economic and financial documents. Will highlight the similarities and differences in the performance of these two companies in context of market developments machinery industry. Companies emerged as a small workshop in the first decades of the twentieth century, evolved with the specific market where it operated with great changes in the 1920 and 1930 and signed in the sector after a decade 1940. In the 1960's were the main companies in the sector in which they operated. 


\section{1_Introdução}

A industrialização constituiu, historicamente, $o$ fator mais poderoso no processo de aceleração do crescimento econômico. O setor industrial exerceu impacto dinâmico sobre outros setores da economia e sobre todo o ambiente social e institucional.

A indústria de máquinas e equipamentos é o setor-chave no processo de industrialização e desenvolvimento econômico de um país, fornecendo máquinas e equipamentos que transformam as condições de produção da agricultura e da indústria. Além disso, essa indústria é importante para o desenvolvimento econômico porque incorpora novos conhecimentos tecnológicos ao processo produtivo, por meio da introdução de novos bens de capital que elevam a produtividade e a eficiência do sistema econômico.

A indústria mecânica possui característica especial,uma vez que seu desenvolvimento dá apoio à expansão de outros setores industriais, ou seja, seus produtos são destinados a aparelhar os outros setores por meio da oferta de máquinas e equipamentos. A forma mais comum de aperfeiçoamento técnico no processo de industrialização dá-se mediante mudanças tecnológicas, principalmente com o desenvolvimento de máquinas para construir máquinas. Portanto, o desenvolvimento da indústria mecânica é fundamental no processo de industrialização. ${ }^{1}$

Neste artigo analisaremos a evolução do mercado da indústria de máquinas e equipamentos no Brasil e em São Paulo, tendo como objeto de estudo duas empresas importantes para o fortalecimento dessa indústria no país, a Dedini e a Romi. A escolha dessas empresas deve-se à existência de estudos específicos e acervos históricos com documentos econômico-financeiros. Serão destacadas as semelhanças e as diferenças no desempenho dessas duas empresas no contexto da evolução do mercado da indústria de máquinas e equipamentos. A motivação para realizar essa pesquisa é entender as origens e a evolução das empresas de máquinas e equipamentos no Brasil, antes do Plano de Metas, período clássico de análise da literatura para a industrialização brasileira.

O presente trabalho insere-se no campo de estudo da História Empresarial, como estudo de caso de empresas. Sua relação com a História Econômica dá-se por meio de estudo de empresas para trazer luz sobre o entendimento de temas como as origens da indústria no Brasil, especificamente da indústria de máquinas em São Paulo, o papel do empresário e a origem do capital no processo de industrialização e desenvolvimento econômico do país. ${ }^{2}$

A próxima seção examina a evolução da indústria de máquinas e equipamentos em perspectiva histórica e levanta algumas hipóteses para o presente trabalho. A terceira seção faz uma análise histórica de Mário Dedini e Emílio Romi e suas empresas. A quarta seção é a contribuição empírica do trabalho no qual analisa a evolução do mercado de cada empresa, identificando os principais clientes e concorrentes. A quinta seção resume as principais conclusões do artigo.

\section{2_A evolução da indústria de máquinas $e$ equipamentos em perspectiva histórica}

Esta seção tem como objetivo examinar a evolução da indústria de máquinas e equipamentos em perspectiva histórica em países desenvolvidos (Inglaterra, Europa Continental e Estados Unidos) e levantar algumas hipóteses que serão confrontadas pelo exame específico da evolução da Dedini e Romi entre 1920 e 1960 . As questões específicas a serem examinadas serão as mudanças na indústria de máquinas e equipamentos ao longo do processo de industrialização. Uma das hipóteses do trabalho é que houve evolução de pequenas oficinas para empresas maiores, como fábricas, nas firmas da indústria de máquinas examinadas entre 1920 e 1960. 
Estudos recentes têm sustentado que a grande conquista da Revolução Industrial britânica foi a criação da primeira indústria mecânica de grande porte que poderia produzir máquinas em massa, aumentando sua produtividade. A produção de máquinas, segundo Robert Allen, foi a base de três desenvolvimentos que explicam o contínuo crescimento econômico mundial até a Primeira Guerra Mundial. Os três desenvolvimentos foram: a mecanização geral da indústria, as ferrovias e a indústria naval movida à energia a vapor. A mecanização da indústria aumentou a produtividade da Grã-Bretanha, e as ferrovias, os navios e a energia a vapor criaram uma economia global, que, com o aumento da divisão do trabalho, foi responsável pela elevação do padrão de vida em toda a Europa. Até meados do século XIX, a Grã-Bretanha teve estrutura industrial desequilibrada, em que o algodão era produzido em fábricas altamente mecanizadas, enquanto o restante da indústria manufatureira produzia de forma tradicional. A partir de meados do século XIX, as máquinas propagaram-se para outras partes da indústria britânica, e essa foi uma das causas do contínuo crescimento da renda. Até esse período, a indústria do algodão foi o mercado mais importante do setor de máquinas na Inglaterra (Allen, 2006, p. 29-30).

Alguns autores têm sustentado que a passagem das ferramentas rudimentares para as máquinas durante a Revolução Industrial foi muito mais lenta do que se costuma descrever. Os principais usuários iniciais de ferramentas (geralmente talhadeiras e limas) foram carpinteiros e construtores de moinhos, que utilizavam práticas rudimentares"a olho e pelo tato". Com a passagem para a utilização das máquinas, maquinistas e engenheiros tornaram-se os principais usuários de instrumentos mecanizados de precisão e trabalhavam de acordo com especificações e projetos. A mudança não foi rápida porque, apesar de os artesãos do século XVIII estarem familiarizados com grande variedade de máquinas (tornos, furadeiras, brocas e máquinas de cortar), essas eram pouco precisas e muito lentas, porém adequadas para a indústria da época. O progresso técnico na indústria de máquinas inicialmente foi implementado por artesãos criativos, que modificaram instrumentos antigos e projetaram novos, ou seja, a mudança foi gradual e cumulativa (Landes, 2005, p. 100).

O ritmo do progresso técnico não pode ser medido com precisão na indústria de máquinas do período inicial da Revolução Industrial em razão do anonimato dos aperfeiçoamentos e pela variação entre instrumentos do mesmo nome, tornando incerto o momento de introdução da inovação. Apesar de não ser possível analisar o progresso técnico com precisão, é possível relatar tendências. Entre duas gerações, as técnicas metalúrgicas progrediram com as ferramentas, tornando-as mais pesadas, automáticas, precisas, versáteis e fáceis de operar. Na metade do século XIX, alguns fabricantes e construtores de máquinas operavam com modelos padronizados, sendo possível a venda a partir de descrições em catálogos. Esse progresso aconteceu "graças, em grande parte, a muitas pessoas talentosas que aprendiam umas com as outras e que formaram uma espécie de família de fabricantes de instrumentos" (Landes, 2005, p. 101).

Não obstante o progressivo aperfeiçoamento das máquinas, no período inicial da Revolução Industrial, elas não possuíam grande precisão e não revolucionaram o modo de produção e o ritmo do trabalho. $\mathrm{O}$ artesão trabalhava ainda com padrões tradicionais, com especificações pouco uniformes e com controle sobre seu desempenho. No entanto, já havia iniciado a transição para um novo tipo de construção mecânica que iria possibilitar a produção em massa a preços acessíveis de bens de consumo modernos no século XX, tais como a bicicleta, o automóvel, geladeiras e televisores. As peças intercambiáveis, ou seja, partes muito precisas que se encaixam e se integram com outras em um equipamento maior, geralmente elaboradas com o uso de um gabarito, 
foram essenciais para essa revolução. Entretanto, no período inicial da Revolução Industrial, os produtos não eram comparáveis às peças intercambiáveis. A utilização do gabarito para a produção das peças das máquinas ainda era uma exceção em meados do século XIX, mas essa prática disseminou-se rapidamente depois desse período: "Vários fabricantes de máquinas [...] vinham há muito tempo servindo-se de moldes e matrizes para facilitar a execução das operações repetitivas. A uniformização dos padrões da fabricação de parafusos e pinos [...] só ocorreu na segunda metade do século [XIX]" (Landes, 2005, p. 102).

A indústria de máquinas-ferramenta foi fundamental para a industrialização britânica entre 1850 e 1914. Apesar de sua importância, essa indústria foi geralmente pequena, empregou poucos homens, embora esses fossem mais qualificados do que em outros setores industriais. $\mathrm{O}$ valor monetário da produção do setor foi baixo relativamente a outros setores industriais. Entre meados do século XIX até a Primeira Guerra Mundial, houve expansão da indústria mecânica britânica. Esse tipo de expansão foi mais comum com novas firmas entrando no setor do que com velhas firmas produzindo novos produtos. Havia alta mobilidade de firmas no setor, com baixas barreiras à entrada e à saída, revelando que a indústria era altamente competitiva. Entre 1877 e 1907, houve aumento de especialização, ou seja, aumento do percentual de firmas que produziam apenas um produto, mas alguns ramos foram muito mais especializados do que outros. A média das firmas da indústria mecânica tornou-se mais especializada na segunda metade do século XIX, mas o setor já era altamente especializado em 1877 (Floud, 1976, p. 1-15).

$\mathrm{O}$ aumento da especialização e a diferenciação na indústria mecânica britânica foram uma resposta do setor ao desenvolvimento de novos produtos e técnicas na segunda metade do século XIX. Como a indústria de máquinas-ferramenta foi fornecedora primária de máquinas para a produção de novos produtos, houve a necessidade de mudança técnica constante. $\mathrm{O}$ desenvolvimento tecnológico na indústria de máquinas-ferramenta entre 1850 e 1914 foi um processo constante de acumulação de conhecimento, e não uma série de invenções isoladas, como no período anterior. A maioria das ferramentas foi inventada antes de 1850. As mudanças na indústria de máquinas-ferramenta foram menores no período de 1850 a 1914 em comparação ao período inicial de desenvolvimento, mas essas mudanças fizeram muita diferença para a produtividade do setor (Floud, 1976, p. 20-23).

A indústria de máquinas do continente europeu, segundo David Landes, teve sua origem na década de 1820, sendo os franceses e os belgas os pioneiros na concepção das próprias máquinas. Em meados do século XIX a Alemanha desenvolveu uma produção independente de máquinas, mas seus produtores tinham dificuldade de encontrar materiais locais adequados, e muitas firmas compravam máquinas-ferramenta mecânicas auxiliares do exterior. O desenvolvimento de uma indústria mecânica no continente foi possível devido a um conjunto de fatores como a importação de mão de obra inglesa, empenho dos governos, altas barreiras tarifárias e outros tipos de restrições à concorrência externa.A expansão da indústria continental iniciou-se com a imitação e a reprodução dos modelos ingleses, com algumas poucas alterações para atender a necessidades específicas locais (Landes, 2005, p. 185).

$\mathrm{A}$ indústria de máquinas do continente era muito menor do que a inglesa, e poucas empresas eram capazes de exportar nesse período inicial de desenvolvimento. Não obstante a indústria se dividir em setores de equipamentos leves e pesados, como na Inglaterra, não havia no continente a produção exclusiva de ferramentas mecânicas. Havia limitação da escala de produção que se refletia na baixa divisão do trabalho dentro da indústria mecânica, e os produtores 
locais precisavam aceitar encomendas de produtos muito diferentes, como locomotivas e motores navais até aparelhos de destilação e tornos mecânicos. Houve poucas iniciativas de padronização, com exceção no setor de máquinas de fiação, já que neste setor havia demanda suficiente que resultaria na introdução de novos modelos de máquinas. A produção de máquinas e equipamentos no período inicial de desenvolvimento dessa indústria no continente era feita por encomenda, onde cada novo pedido costumava ser diferente do anterior. Não havia produção de peças intercambiáveis, o trabalho era pouco padronizado e os operadores de máquinas utilizavam a lima como principal instrumento de trabalho (Landes, 2005, p. 186).

As características da indústria de máquinas no continente faziam com que algumas indústrias de bens de consumo, como a indústria têxtil, produzissem as próprias máquinas em oficinas especializadas. As empresas de bens de consumo menores dependiam de técnicos e mecânicos locais, já que esses ofereciam assistência técnica imediata, facilitando a manutenção do equipamento. As oficinas de consertos foram fábricas embrionárias onde o progresso empresarial foi rápido para muitos mecânicos de poucos recursos, com autofinanciamento pelos seus lucros e alguns empréstimos. Entretanto, a especialização da indústria de máquinas no continente aconteceria apenas na segunda metade do século XIX, com o aumento da demanda da indústria de mineração, metalurgia e principalmente pela construção de ferrovias (Landes, 2005, p. 186-187).

O desenvolvimento da indústria mecânica nos Estados Unidos foi possível com a "revolução nos transportes". Os produtores de máquinas especializadas surgiram no mercado americano após 1840, coincidindo com a expansão da rede nacional de ferrovias. Assim, até a década de 1840, a produção de máquinas foi pouco especializada, cada firma produziu uma ampla variedade de produtos que atendiam um raio geográfico limitado, ou seja, uma operação altamente localizada por causa do alto custo do transporte das máquinas. Depois de 1840, com a redução no custo dos transportes, houve crescente especialização na produção de máquinas, com o surgimento de grande número de produtores que se concentravam em uma faixa estreita de máquinas. A redução do custo do frete ampliou o mercado, o que resultou no aparecimento de produtores especializados, já que produtores altamente especializados não podiam produzir para um mercado restrito geograficamente (Rosenberg, 1963a, p. 220-222).

Durante a primeira metade do século XIX, nos Estados Unidos, o setor de armas de fogo ocupou posição central no desenvolvimento de uma maquinaria de precisão especializada, principalmente de máquinas de trituração e o torno revólver, que juntos foram indispensáveis à produção de todos os produtos baseados em peças intercambiáveis. O torno revólver foi adaptado e modificado para utilização em várias atividades como a produção de componentes para máquinas de costura, relógios, máquinas de escrever, locomotivas, bicicletas e eventualmente automóveis. As exigências técnicas na indústria de máquinas de costura, entre 1850 e 1870, possibilitaram modificações importantes para essa indústria, que transbordaram para outros setores como calçados, roupas; a máquina foi usada extensivamente em 1890 na produção de toldos, tendas, velas, livros de bolso, bens de borracha e elástico, selaria, arreios e encadernação de livros. A difusão da máquina de costura depois de 1860 é um grande exemplo de convergência tecnológica. Essa difusão foi possível graças ao fornecimento de um dispositivo mecânico altamente eficaz para a realização de uma operação comum entre muitas indústrias.

As soluções dos problemas de fabricação de bicicletas viabilizada por novas máquinas-ferramenta foram aproveitadas pelos produtores de automóveis. O período entre 1880 e 1910 se caracterizou pelo aumento e pelo desenvolvimento 
de máquinas-ferramenta para fins altamente especializados, com contínua adaptação de técnicas estabelecidas, novas formas de uso e melhora sistemática nas propriedades dos materiais empregados na fabricação de máquinas-ferramenta. $\mathrm{O}$ crescimento do volume na produção manufatureira foi acompanhado por convergência tecnológica em grandes grupos de indústrias, que resultou em crescimento de processos de especialização, possibilitando a produção e a difusão de novo conhecimento técnico. As pequenas melhoras na produção tenderam a criar os próprios problemas futuros, que obrigaram a uma nova alteração e revisão (Rosenberg, 1963b, p. 426-443).

Ross Thomson analisou como e quão ampla foi a convergência tecnológica entre as máquinas-ferramenta e as indústrias nos Estados Unidos, entre 1815 e 1930. Segundo o autor, a convergência envolveu a invenção e a difusão de máquinas-ferramenta e ambas ocorreram de várias formas. Nesse período, o setor de máquinas-ferramenta passou por três fases de progressiva ampliação da convergência. Até 1865, as empresas produziam as próprias máquinas-ferramenta,e a invenção era usada na própria firma. Nesse período, a convergência tecnológica foi muito pequena, ocorrendo através da diversificação da maquinaria das empresas, vendas incipientes de máquinas para propósitos gerais e mobilidade de trabalhadores. Entre 1865 e 1890, o setor de máquinas-ferramenta tornou-se central para a invenção e a ampliação de máquinas-ferramenta entre as indústrias. A convergência foi realizada por trabalhadores treinados das firmas de máquinas-ferramenta, com o aumento da mobilidade de trabalho entre firmas, a formação de outras firmas por esses trabalhadores e alguma diversificação no setor. Após 1900, o setor de máquinas-ferramenta manteve o papel central na invenção e na difusão tecnológica para indústrias estabelecidas, automóveis e outras novas indústrias. Entretanto, inovações surgiram nas indústrias de aço e elétrica, como novos recursos para as máquinas-ferramenta, sendo que as ciências dos materiais e a eletrificação influenciaram as indústrias metalúrgicas (Thomson, 2010, p. 5).

Depois de verificarmos as principais características da evolução e do desenvolvimento da indústria de máquinas e equipamentos na Inglaterra, na Europa continental e nos Estados Unidos, voltaremos a atenção para os fatores que explicam o aparecimento de uma indústria de máquinas e equipamentos em uma economia periférica como o Brasil e, especificamente, dentro da província e depois Estado de São Paulo, no início do século XX.

Neste ponto, é possível apontar algumas hipóteses para a origem e a evolução de uma indústria de máquinas e equipamentos em São Paulo, no início do século XX. Assim, possivelmente as características do setor, como necessidade de manutenção técnica de máquinas e ferramentas próximas ao local onde estavam instaladas, oferta de empreendedores e mão de obra de técnicos especializados resultante da imigração e baixa necessidade de capital para a entrada no setor de manutenção, poderiam ser consideradas importantes. $O$ alto crescimento da produção industrial e a oferta de trabalhadores imigrantes relativamente qualificados podem ter fornecido as condições para a gênese de uma indústria de máquinas no Estado de São Paulo. Algumas empresas de máquinas e equipamentos como a Dedini e a Romi iniciaram suas atividades como pequenas oficinas e evoluíram para fábricas, conforme o mercado brasileiro se ampliava, como relataremos nas próximas seções.

\section{3_As origens de Mário Dedini e Américo Emílio Romi e suas empresas}

Nascidos na última década do século XIX, Mário Dedini (1893-1970) e Américo Emílio Romi (1895-1959) foram contemporâneos. O primeiro é da cidade de Lendinara, situa- 
da na província de Rovigo, próxima de Pádua e de Ferrara, no Norte da Itália. O segundo nasceu no Brasil, na cidade de São José do Rio Pardo (Estado de São Paulo), filho de imigrantes italianos, também do Norte da Itália.

Ambas as famílias vieram para o Brasil por causa dos problemas econômicos e da instabilidade política da Europa, no final do século XIX e início do século XX, e pela possibilidade de progresso econômico nas Américas. Ambos tinham alguma relação com as atividades econômicas agrícolas, mas também tinham conhecimentos da mecânica. Mário Dedini nasceu em uma região produtora de açúcar de beterraba na Itália. Mário estudou desenho mecânico na Escola Técnica de Lendinara e trabalhou na usina de açúcar de beterraba da cidade, uma das maiores daquele país. Desde muito jovem, Mário Dedini conhecia as ramificações possíveis do açúcar com a mecânica, na manutenção de equipamentos agrícolas para o setor. Sua vinda para o Brasil foi resultado da ligação com a atividade na usina de açúcar. O convite de um amigo que prestava serviços para a produção açucareira paulista motivou o jovem Mário, que, em 1914, saiu do porto de Gênova e chegou ao porto de Santos e aí se dirigiu para a fazenda Amália, na cidade de Santa Rosa de Viterbo, no interior de São Paulo.

Dois anos antes da chegada de Mário Dedini ao Brasil, em 1912, Américo Emílio Romi e sua família, que veio para o país motivado pelo trabalho nas fazendas de café do interior do Estado de São Paulo, retornam à Itália. O pai de Emílio Romi tinha conhecimentos de mecânica e trabalhou na construção da ponte metálica sobre o Rio Pardo, com Euclides da Cunha, em 1896. Em 1900, a família mudou-se para Casa Branca, e seu pai conseguiu empregar-se como maquinista da Cia. Mogiana de Estrada de Ferro, permanecendo no emprego até 1906. Depois desse período, a família acumulou algum dinheiro e resolveu voltar à Itália para proporcionar educação aos seus filhos. Na Itália, em 1912,
Américo Emílio estudou Eletromecânica começou sua atividade profissional como mecânico na fábrica da Tecnomazio Brown-Boveri, em Milão. A partir de 1915, Romi serviu na Primeira Guerra Mundial, consertando caminhões e veículos militares para a Itália, revelando suas habilidades mecânicas. Romi voltaria ao Brasil, em 1923, para trabalhar como mecânico em um revendedor Ford, em Santo Amaro (Exame, 1973, p. 51-52; Visão, 1961, p. 22-23).

Mário Dedini, ao chegar ao Brasil, em 1914, foi encaminhado da fazenda Amália à usina Santa Bárbara. Mário Dedini auxiliou os engenheiros e os técnicos franceses na montagem da usina, com equipamentos importados, em sua maior parte, da França. Como Mário já conhecia a técnica da produção de açúcar de beterraba, sua experiência facilitou o aprendizado da técnica de fabricação de açúcar de cana. Em 1915, Mário Dedini tornou-se o primeiro gerente não engenheiro da usina.

Em 1924, Emílio Romi mudou-se com a família para a Vila Americana, que pertencia ao município de Piracicaba, em busca de novas oportunidades de trabalho. Com suas habilidades em mecânica, encontrou emprego em uma oficina Chevrolet, onde adquiriu grande número de clientes e passou a ganhar o maior salário de mecânico da região. Entre 1927 e 1929, Romi mudou-se novamente, agora para Santa Bárbara do Oeste (Exame, 1975, p. 51-52; Exame, 1973, p.51-52; Negri, 1977, p. 1-2; Leão, 2005, p. 47-48).

Como é possível perceber, Mário Dedini e Américo Emílio Romi percorreram a mesma região geográfica do interior paulista, apesar de momentos diferentes. Uma hipótese advém do fato de que as fazendas agrícolas (de café, cana-de-açúcar, por exemplo) da região Nordeste e Central do Estado de São Paulo atraíram imigrantes que possuíam outras habilidades além do trabalho na lavoura. Essa atração pode ser explicada pela existência de estradas de ferro na região e das fazendas com engenho e café, que requeriam manutenção 
para seus equipamentos (locomotivas, vagões, máquinas de beneficiamento agrícola, caldeiras e moendas de cana-deaçúcar, carroças, automóveis e outros implementos agrícolas).

Mário Dedini e Américo Emílio Romi iniciaram os próprios negócios com pequenas oficinas. O primeiro, uma oficina de carpintaria e ferraria para a fabricação e o conserto de veículos (troles, carroças, carroções, charretes) e utensílios agrícolas (bicos de grades, bicos de arados para tração animal, e outros tipos de arados), em 1920, na cidade de Piracicaba. Já o segundo iniciou suas atividades na cidade de Santa Bárbara, em 1929, com uma oficina de automóveis, na qual produzia peças e que passou a receber encomendas de peças de equipamentos agrícolas.

Em 1920, Mário Dedini deixaria suas atividades formais na usina Santa Bárbara para dedicar-se à sua oficina, mas continuou dando assistência técnica à usina por vários anos. Assim, em 1922 foi registrada a firma Mário Dedini \& Irmão, conhecida como Oficina Irmãos Dedini, com capital de dez contos de réis. Segundo Barjas Negri, a localização da oficina, na Vila Rezende, em Piracicaba, foi essencial para o desenvolvimento inicial da empresa porque ficava em um corredor de tráfego obrigatório da região. Assim, a firma recebia grande demanda por serviços de reparação de veículos, e a localização estratégica facilitava o atendimento de pedidos de reparação ou fabricação de utensílios agrícolas. A inexistência de oficinas que atendessem às necessidades de reparo de peças para os vários engenhos de açúcar e fábricas de aguardente da região foi um fator essencial para o desenvolvimento da Dedini (Negri, 1977, p. 2-5).

O conhecimento técnico adquirido por Mário Dedini no trabalho em usinas para a produção de açúcar foi fundamental para o atendimento das necessidades de reparo para o setor ligado ao processamento da cana-de-açúcar. Assim, o início da produção de máquinas e equipamentos no interior de São Paulo esteve ligado ao desenvolvimento econômico local ou regional. O desenvolvimento econômico de Piracicaba, no início do século XX, local de instalação da oficina Dedini, é um exemplo dessa ligação entre a agricultura local e o crescimento da indústria. As atividades agroindustriais locais, ligadas ao cultivo e ao processamento da cana-de-açúcar, viabilizaram o aparecimento de empresas para atender à demanda do setor. As primeiras usinas possuíam as próprias oficinas para a manutenção do equipamento e do maquinário, mas o crescimento e o desenvolvimento da produção açucareira resultaram em oportunidades de novos empreendimentos destinados à manutenção das empresas de processamento da cana-de-açúcar, possibilitando condições para o aparecimento de oficinas mecânicas especializadas.

No final dos anos 1920, a Oficina Dedini passou por uma expansão significativa, que constituiu as pré-condições para a formação de uma empresa de máquinas e equipamentos no interior do Estado de São Paulo. A oficina mecânica de reparos de automóveis transformou-se em uma pequena indústria, que tinha como atividade o conserto, a reparação e a construção de peças simples para pequenos engenhos de açúcar. Assim, em 1926, a empresa, na época denominada M. Dedini, instalou uma seção mecânica e uma pequena fundição de ferro, com a aquisição de máquinas de segunda mão. Entre 1926 e 1928, a empresa iniciou a fabricação de conjuntos de moendas de cana, além de eixos, engrenagens, luvas, camisas, mancais, facas, rodetes, entre outros. As moendas eram relativamente simples, constituindo-se em três cilindros horizontais e outras peças de ferro fundido, em sua maior parte acionados por motores elétricos de baixa potência. $\mathrm{O}$ desenho mecânico e o processo de fabricação basearam-se na experiência de Mário Dedini com máquinas para o setor. Assim, no final dos anos 1920, a empresa já havia passado da fase de reforma de peças para a fabricação de máquinas para o setor açucareiro (Negri, 1977, p. 9-11; Leão, 2005, p. 56-58). 
No final do ano de 1929, Romi iniciou o próprio negócio com um capital de apenas dois contos de réis, emprestado por um amigo. Nasceu a Garage Santa Bárbara de Emílio Romi, firma de propriedade individual, com apenas dois operários em uma área de duzentos e cinquenta metros quadrados. Logo depois da fundação, antevendo os efeitos da Crise de 1929 sobre as importações, Emílio Romi comprou uma grande quantidade de peças para automóveis, tornando-se a maior oficina mecânica da região (Exame, 1973, p. 51-52; Romi, 1970, p. 2; Romi, 1970b, p. 66).

Apesar dos efeitos da Crise de 1929, ao longo da década de 1930, tanto a Dedini como a Romi tiveram expansão significativa, resultando em mudanças importantes no processo de produção e nos produtos produzidos. Em 1929, além de consertar automóveis, a empresa de Emílio Romi reparava arados e semeadeiras estrangeiras, produzindo peças para esses produtos. Em 1932, Romi passou de oficina de reparos para a fabricação de máquinas agrícolas. No final de 1933 e início de 1934, os jornais de Santa Bárbara (Cidade de Santa Bárbara e O Bandeirante) noticiaram a inauguração da seção de mecânica e fundição das Oficinas Romi anexa à garagem e à oficina de marcenaria já existente. A fundição era de grande porte e moderna para a cidade no período e estava aparelhada para fabricar quaisquer peças de máquinas exigidas pela indústria local e das cidades vizinhas. A fundição era composta de duas fornalhas, uma para a fundição de ferro, e outra, de bronze, com capacidade de produção de 150 toneladas de peças fundidas por mês. Estava resolvido o problema da fundição de peças de ferro e bronze. Em 1936, Romi comprou seu primeiro torno mecânico, iniciando o aparelhamento do seu maquinário com a expansão do mercado nos anos 1930 (Santa Bárbara, 1933; Bandeirante, 1934; Exame, 1973, p. 52).

Em 1937, a Fábrica de Máquinas Agrícolas Santa Bárbara era uma das unidades industriais mais importantes do município de Santa Bárbara. A empresa possuía setenta e cinco operários em comparação aos quatro mecânicos que iniciaram em 1929, e sua produção anual de máquinas era de quase seiscentos contos de réis (Santa Bárbara, 1937). Em 1938, a firma Américo Emílio Romi tornou-se sociedade limitada, denominando-se Máquinas Agrícolas Romi Ltda., com um capital de trezentos contos de réis. Em 1939, a empresa era a maior fábrica de máquinas agrícolas do Brasil, possuindo prensas de grande tonelagem para a produção dos equipamentos. Seus produtos eram fabricados com métodos modernos, semelhantes às grandes organizações industriais dos Estados Unidos e da Europa. Os produtos eram vendidos aos mais modernos agricultores do país e exportados para países do continente americano (Exame, 1973, p. 52; Diário De São Paulo, 1939, p. 4).

A década de 1930 foi muito favorável para as atividades econômicas da Dedini. Nessa época, houve um processo de expansão e transformação na empresa, com aquisição de maior parcela do mercado, novas linhas de produtos e maior escala na produção. Apesar de a empresa ter se transformado de uma simples oficina de reparos, no início dos anos 1920, em uma empresa de produção de equipamentos, em meados dos anos 1920, sua estrutura de produção ainda era modesta no início da década de 1930 . As máquinas utilizadas pela empresa eram, em sua maioria, de pequeno porte e usadas. No início dos anos 1930, a empresa era composta de uma carpintaria, uma ferraria, uma seção de mecânica, modelagem, caldeiraria e uma fundição de ferro e bronze.

A Crise de 1929 tornou os produtos da Dedini, geralmente moendas para cana-de-açúcar, mais baratos do que os importados. ${ }^{3}$ Ao longo da década de 1930 , as usinas passaram a exigir máquinas e aparelhos de maior porte para a extração de caldo de cana. Os efeitos da Crise de 1929 na economia açucareira paulista não foram tão intensos como em outros Estados. Com a crise do café, os agricultores passaram a di- 
versificar a produção agrícola, beneficiando o setor de cana-de-açúcar. Ao longo da década de 1930, houve crescimento relativo da produção de açúcar para o Estado de São Paulo (de uma participação média do Estado na produção total de açúcar do país de 8,7\% nas safras de 1925/1930 para uma participação de 19,1\% nas safras de 1935/1940), tornando-se esse o segundo maior produtor do país, atrás apenas de Pernambuco.

Esse aumento da participação de São Paulo na produção de açúcar do país é explicado pela elevação do número de usinas no Estado, entre 1929 e 1940, isto é, de 20 para 34. A partir de 1935/1936, o Instituto do Açúcar e do Álcool (IAA) apoiou a modernização e a ampliação das instalações de muitas usinas paulistas. Assim, a participação de engenhos na produção de açúcar de São Paulo caiu de 50\% em 1930 para $25 \%$ em 1940. A cidade de Piracicaba era responsável por 20\% da produção de açúcar do Estado, em 1937. Essa produção era realizada por seis grandes usinas e 265 engenhos. Esse foi um mercado cativo para a empresa de Mário Dedini, que atendia o segmento de máquinas e equipamentos tanto de engenhos como de usinas (Negri, 1977, p. 12-35).

Na década de 1940, as estratégias de desenvolvimento da Dedini e da Romi tomaram rumos diferentes. Durante a Segunda Guerra Mundial, com a interrupção das importações, a Romi decidiu especializar a sua produção e produzir um novo produto, o torno. A Dedini notou a necessidade de complementar os produtos que produzia para as usinas e aprofundou o processo de diversificação de seus produtos, fundando novas firmas para a produção de máquinas e equipamentos para o setor alcooleiro e máquinas especializadas para o setor açucareiro.

A Romi iniciou a produção de tornos mecânicos em 1941. A produção de tornos mecânicos foi intensa, e já em 1943 a firma havia produzido mil unidades. A empresa adotou a estratégia de investir no setor de tornos mecânicos e abandonou a produção de máquinas agrícolas, evitando, assim, uma diversificação prematura. Para reforçar e manter a especialização, a empresa iniciou a exportação desse produto para a América Latina. Em 1946, a Romi exportava em média 40 tornos por mês para a Argentina, atingindo grande participação nesse mercado.

Em 1948, com o auxílio do engenheiro André Toselo, a Romi iniciou a produção do primeiro trator nacional, denominado Toro, baseado no modelo Allis-Chalmers triciclo. Esse trator era mais pesado e mais potente do que seu concorrente direto, tendo um preço mais elevado do que o do modelo da Ford. O preço do primeiro trator nacional inviabilizou seu projeto, e a Romi manteve-se afastada do mercado de veículos automotores até 1954, quando a empresa adquiriu os direitos de fabricar o automóvel Isetta da Iso-Motor, de Milão, Itália. O Romi-Isetta, primeiro automóvel nacional de dois lugares, com apenas $30 \%$ das peças importadas, foi fabricado até 1959, mas o projeto foi encerrado pela empresa porque a política de apoio às empresas automobilísticas pelo Grupo Executivo das Indústrias Automobilísticas para a isenção de impostos para a importação de peças excluiu os automóveis de dois lugares. Assim, seu custo inviabilizou seu sucesso no mercado automobilístico nacional, já que as peças de automóveis de quatro lugares tinham isenção de imposto e taxa de câmbio diferenciada para a importação de peças (Exame, 1973, p. 52-54; Romi, 1970; Romi, 1970b, p. 66-67; Banas, 1970, p. 7-12).

Na década de 1960, a Romi tornou-se uma das principais empresas produtoras de torno do mundo, ficando atrás apenas de uma empresa estatal da União Soviética. A empresa, no final da década de 1960, exportava tornos para diversos países, inclusive da Europa, Japão e Estados Unidos. A empresa vendia tornos com tecnologia local até para uma firma de Cincinatti, região onde se concentravam as três maiores empresas produtoras de torno dos Estados 
Unidos, no final dos anos 1960 (Exame, 1973, p. 52-54; Romi, 1970; Romi, 1970b, p. 66-67; Banas, 1970, p. 7-12).

Na década de 1940, a Dedini diversificou e verticalizou sua linha de produtos diante do crescimento do parque açucareiro e da necessidade de aumento do tamanho dos conjuntos de moendas utilizados pelas usinas. Outro motivo para a diversificação foi a política do Instituto do Açúcar de Álcool para incrementar a produção de álcool. Na década de 1930, cresceu o número de destilarias para a produção de álcool. Em 1933, havia no país apenas uma destilaria de álcool, aumentando para 44 unidades em 1941. Com a diversificação do setor alcooleiro, surgiu outra oportunidade no mercado de máquinas voltadas para o setor canavieiro: a produção de máquinas e equipamentos para destilarias. Assim, com tal conjuntura favorável, a família Dedini, em sociedade com Waldomiro Perissinotto e Lázaro Pinto Sampaio, fundou a Construtora de Destilarias Dedini, ou Codistil, em 1943. O objeto social da Codistil era a fabricação e o comércio de máquinas, alambiques, aparelhos, peças, acessórios, instalações do ramo e montagem de destilarias para aguardente e álcool. No início, a empresa produziu apenas alambiques e caldeiras de pequena capacidade, além de reformar e consertar os equipamentos existentes. Em 1945, a empresa já estava produzindo equipamentos para destilarias completas. Em 1953, a Codistil havia fabricado 140 destilarias para aguardente e 30 para álcool (Leão, 2005, p. 76-92; Exame, 1975, p. 53-54).

No final dos anos 1940 e início dos anos 1950, a Dedini aprofundou o processo de diversificação e verticalização com a associação da família à Metalúrgica de Acessórios para Usinas S.A. - Mausa -, da qual Mário Dedini conseguiria total controle. A Mausa produzia equipamentos para usinas não fabricados pela Dedini e pela Codistil e que exigiam maior conhecimento técnico para sua elaboração. A empresa fabricava produtos cuja tecnologia ainda não era de domínio público, como filtros de caldos, filtros rotativos, centrífugas, decantadores, redutores de velocidade, bombas, mesas alimentares de cana, pontes rolantes e outros (Leão, 2005, p. 76-92; Exame, 1975, p. 53-54).

Em 1947, a Dedini tinha capacidade de fabricar usinas completas para a produção de açúcar, indicando alto grau de diversificação e verticalização de seu sistema produtivo. Em 1954, as moendas produzidas pela empresa aumentaram de dimensão. Assim, logo após o final da Segunda Guerra Mundial, a Dedini tinha capacidade de produzir todos os equipamentos necessários dentro das usinas nacionais. Já em 1945, a empresa deixou de ser firma individual e passou a denominar M. Dedini \& Cia. Em 1950, Dedini é transformada em sociedade anônima, estando as três empresas do grupo (Dedini Metalúrgica, Codistil e Mausa) aptas para atender à demanda de equipamentos do complexo canavieiro brasileiro (Leão, 2005, p. 76-92; Exame, 1975, p. 53-54).

\section{4_A evolução do mercado interno e externo}

\section{1_0 mercado de máquinas para a \\ agricultura canavieira e a Dedini}

Na agricultura canavieira em São Paulo, no final do século XIX e início do século XX, a demanda por máquinas era realizada por grande quantidade de pequenos engenhos e de usinas. As primeiras empresas produtoras de máquinas para o setor canavieiro iniciaram suas atividades como oficinas de reparos e produção de peças para máquinas importadas, sendo de extrema importância a localização geográfica da oficina em relação à usina ou ao engenho.

Segundo Barjas Negri, o fator mais importante para o desenvolvimento de oficinas foi a assistência técnica oferecida por elas. A assistência era extensiva a todos os aparelhos da usina, e a proximidade entre oficina e usina possibilitava a reposição de peças em tempo menor do que com as 
importações. Assim, "em virtude desta capacidade de reparação e reposição rápida as usinas não mais precisariam importar antecipadamente aquelas peças importantes que normalmente apresentavam quebras frequentes durante 0 período de fabricação de açúcar." (Negri, 1977, p. 15)

Em 1920, ano da fundação da oficina de Mário Dedini, o maior mercado consumidor dos serviços da oficina eram os vários pequenos engenhos localizados na região de Piracicaba. Os serviços de manutenção eram realizados na zona rural, ou seja, o atendimento era no próprio engenho. $\mathrm{O}$ atendimento às usinas, unidades de produção mais modernas e complexas, aumentou no final dos anos 1920.A Tabela 1, a seguir, mostra os principais clientes de Mário Dedini entre 1929 e 1945 . O primeiro conjunto completo de moendas, com todos os acessórios, com capacidade de moer cerca de 100 toneladas de cana por dia, fabricado pela Dedini, foi vendido para a usina Nossa Senhora Aparecida, de Virgolino de Oliveira, em Itapira, no ano de 1929. Em 1932, Dedini reformou as máquinas e os equipamentos adquiridos por Pedro Ometto para instalação da usina Boa Vista, em Iracemápolis. Esses equipamentos eram maiores e mais complexos dos que os produzidos até aquele momento, possibilitando à empresa acumular conhecimento técnico, que iria deixá-la apta para a modernização das usinas incentivada pelo Instituto do Açúcar e Álcool nos anos 1930 (Negri, 1977; Leão, 2005).

Outra característica da abordagem do mercado consumidor pela Dedini foi o método comercial peculiar de venda de seus produtos. A empresa aceitava equipamentos usados como parte depagamento na compra de equipamentos novos. Desse modo, reformava os equipamentos antigos e vendia-os para usinas de menor porte. Essa política de venda fazia com que os usineiros antecipassem suas decisões de modernizar e ampliar suas usinas, aumentando, assim, a capacidade de produção de açúcar paulista. A prática de reforma de equipamentos usados possibilitava para a empresa a assimilação tecnológica dos produtos. Muitas vezes o usineiro comprava equipamentos do exterior ou de outras usinas e encomendava a reforma na empresa de Mário Dedini. Segundo Barjas Negri, essa política de comercialização proporcionava um "veículo irradiador do progresso técnico dentro da indústria açucareira” (Negri, 1977, p. 30). Tal política estimulou a modernização do setor açucareiro, resultando em processos de produção mais racionais, eficientes e de maior escala.

\section{Tabela 1_Principais clientes da Dedini, 1929-1945}

\begin{tabular}{|c|c|c|c|}
\hline Usinas & Proprietários & Município & Ano \\
\hline $\begin{array}{l}\text { Nossa Senhora } \\
\text { Aparecida }\end{array}$ & Virgolino de Oliveira & Itapira-SP & 1929 \\
\hline Boa Vista & Pedro Ometto & Iracemápolis-SP & 1932 \\
\hline Costa Pinto & Ometto, Bassinello e Dedini & Piracicaba-SP & 1936 \\
\hline $\begin{array}{l}\text { São Francisco } \\
\text { do Quilombo }\end{array}$ & Ometto, Dedini, Oliveira & Charqueada-SP & 1942 \\
\hline $\begin{array}{l}\text { Bandeirantes } \\
\text { do Paraná }\end{array}$ & Dedini, Ometto,Meneghell & Bandeirantes-PR & 1942 \\
\hline Pedra & Pedro Biagi & Serrana-SP & 1931 \\
\hline Santa Cruz & Giuseppe Annichino & Capivari-SP & 1926 \\
\hline Santa Elisa & - & Sertãozinho-SP & 1936 \\
\hline Santa Lucia & Jerônimo Ometto & Araras-SP & 1940 \\
\hline São João & José Ometto & Araras-SP & 1935 \\
\hline Paraíso & - & Charqueada-SP & - \\
\hline Porto Real & - & Floriano-RJ & - \\
\hline $\begin{array}{l}\text { Fundação } \\
\text { Brasil Central }\end{array}$ & - & Rio Doce-GO & 1943 \\
\hline
\end{tabular}

Fonte: Negri, 1977, p. 12-35; Leão, 2005, p. 63-73.

Nota: Nas usinas da Pedra, Santa Cruz, Santa Elisa, Santa Lucia, São João, Paraíso, Porto Real e Fundição Brasil Central, o ano representa a data da fundação da usina. Nas outras usinas, o ano representa a aquisição de equipamentos da Dedini. 
Outra iniciativa de Mário Dedini que resultou em aprendizado tecnológico para a empresa foi a associação com interessados em investir no setor açucareiro. Geralmente, os interessados em investir no setor eram fornecedores, plantadores de cana-de-açúcar que desejavam instalar engenhos para processar cana ou produtores de açúcar que desejavam ampliar suas instalações ou transformá-las em usinas, com equipamentos mais modernos. $\mathrm{O}$ objetivo inicial dessa associação era ampliar o mercado para os equipamentos e os serviços oferecidos pela Dedini. Assim, a ampliação do mercado resultava em nova alimentação da demanda no futuro para os produtos e os serviços da Dedini. Essa demanda tornava-se cativa porque anualmente havia necessidade de reposição de peças para os equipamentos, e, caso desejasse ampliar suas instalações, a usina ou o engenho recorreria à empresa que forneceu os primeiros equipamentos, já que as unidades produtoras eram projetadas para que pudessem realizar ampliações da capacidade produtiva.

A associação era realizada como uma oportunidade tanto para o plantador de cana-de-açúcar como para o fornecedor de máquinas e equipamentos, visto que o primeiro teria a disponibilidade dos serviços de manutenção dos equipamentos rapidamente. Desse modo, Mário Dedini participava como sócio, contribuindo com os equipamentos produzidos pela empresa, portanto, com uma parte do capital físico da usina. Essas usinas associadas à Dedini funcionavam como um laboratório para os produtos da firma. Havia constantes aperfeiçoamentos e testes dos produtos nas usinas onde a empresa tinha participação.

Em 1936, Mário Dedini realizou sua primeira grande associação com produtores de açúcar, participando da constituição da usina Costa Pinto Ltda., na cidade de Piracicaba. Mário Dedini assumiu 25\% (150 contos de réis de um total de 600 contos de réis) do capital da usina; Pedro Ometto possuía $50 \%$ do capital (300 contos de réis); João Ometto, mais
17\% (100 contos de réis); e João Bassinelo, outros $8 \%$ (50 contos de réis). Os equipamentos da usina Costa Pinto foram em sua maior parte fornecidos pela Dedini e alguns importados da Europa. A Dedini forneceu a manutenção das máquinas e equipamentos e reposição das peças para a usina desde a fundação e também foi responsável por sua ampliação, em 1944, e todos os novos equipamentos foram fornecidos pela empresa de Mário Dedini.

Em 1942, outras associações ampliaram a atuação da família Dedini como fabricante de equipamentos para o setor açucareiro e proprietária de usinas: a constituição da Usina São Francisco do Quilombo Ltda., localizada em Charqueada, próxima a Piracicaba, e a Usina Bandeirantes do Paraná Ltda., localizada em Bandeirantes, no Estado do Paraná. A Usina São Francisco do Quilombo foi constituída pela filha de Mário Dedini, Nida Corrente Dedini, o filho de Pedro Ometto, Dovílio Ometto, e por Virgolino de Oliveira, em três partes iguais de 200 contos de réis. A Usina Bandeirantes tinha como sócios Nida Corrente Dedini, com 30\% do capital da empresa; a família Ometto, com 18\%; a família Meneghell, com 30\%; Manoel Moreno Filho, com 12\%; e José Viziolli, com 10\%. Ambas as usinas foram equipadas com os produtos da Dedini. As usinas São Francisco do Quilombo e a Bandeirantes receberam participação maior dos equipamentos da Dedini no total de equipamentos adquiridos do que a usina Costa Pinto, porque a empresa de Mário Dedini estava produzindo grande quantidade de equipamentos em 1942, que ainda não produzia em 1936 (Negri, 1977, p. 30- 31; Leão, 2005, p. 74).

Os principais sócios da família Dedini nos empreendimentos relacionados às usinas foram Pedro Ometto e Virgolino de Oliveira. Os negócios entre eles favoreceram relações de longa amizade dos três empresários. É importante notar que as relações que transformaram Pedro Ometto em um dos maiores produtores de açúcar do país e Mário Dedini no 
maior fabricante de máquinas e equipamentos para o setor foram pautadas em laços de compadrio e alicerçadas e institucionalizadas pelo casamento de seus filhos, Dovilio Ometto e Ada Dedini. Dovilio Ometto, depois de formado em Engenharia Agronômica na "Luiz de Queiroz", começou a trabalhar na Dedini, em meados dos anos 1940, e tornou-se sucessor de Mário, seu sogro, nas empresas da família (Leão, 2005, p. 70, 90-91).

Outras usinas ligadas à família Ometto que adquiriram equipamentos da Dedini foram a Santa Lúcia e a São João, ambas na cidade de Araras. Outros importantes clientes da Dedini, ao longo desses 35 anos de atividades, foram as usinas da Pedra, em Serrana; Santa Cruz, em Capivari; Santa Elisa, em Sertãozinho; Paraíso, em Charqueada, todas no Estado de São Paulo, além da usina Porto Real, no Rio de Janeiro, e da Fundação Brasil Central, em Goiás (ver Tabela 1).

Em meados das décadas de 1940 e 1950, a Dedini manteve a estratégia de ampliar o mercado participando de sociedade de novas usinas. Entre 1946 e 1956, a Dedini ou seus proprietários participaram da sociedade de mais cinco usinas que a empresa montou e forneceu equipamentos: a usina Modelo, da Barra, Santa Helena e Sant'ana, no interior de São Paulo, e a Fronteira, em Frutal, Minas Gerais. É nesse período que a empresa firmou-se como grande empresa nacional fornecedora de equipamentos para o setor canavieiro. Apesar do deslocamento das usinas para a região Centro-Sul do país (as usinas de São Paulo passam de 42 em 1946 para 92 em 1956), a Dedini passou a atender o mercado nacional (Negri, 1977, p. 45).

Entre 1947 e 1952, o valor das vendas do grupo Dedini aumentou em cinco vezes em termos reais, com uma taxa de crescimento anual de 31,6\% (ver Tabela 3). No início dos anos 1950, a Dedini contava com mais de dois mil clientes em todo o país. Nesse período, a Dedini havia fabricado 64 usinas completas e 178 equipamentos de moagem. A maior parte desse mercado estava em São Paulo, mas a empresa também
Tabela 2_Principais clientes da Dedini, 1946-1956

\begin{tabular}{l|l|c} 
Usinas & Município & Ano \\
\hline Modelo & Piracicaba-SP & 1946 \\
\hline Barra Grande & Lençóis Paulista-SP & 1947 \\
\hline Adelaide & Ilhota-SC & 1947 \\
\hline Fronteira & Frutal-MG & 1948 \\
\hline da Barra & Barra Bonita-SP & 1950 \\
\hline Tamanduá & Charqueada-SP & 1951 \\
\hline Santa Helena & Rio das Pedras-SP & 1951 \\
\hline Santo Antonio & Piracicaba-SP & 1952 \\
\hline Bom Jesus & Rio das Pedras-SP & 1952 \\
\hline Sant'ana & Ourinhos-SP & 1954 \\
\hline São José & Rio das Pedras-SP & 1956 \\
\hline
\end{tabular}

Fonte: Negri, 1977, p. 68

Nota: As usinas Modelo, Fronteira, da Barra, Santa Helena e Sant'ana tinham a Dedini ou seus proprietários como participantes da sociedade.

atendia principalmente a demanda de usinas em Minas Gerais, no Paraná e em Santa Catarina (Leão, 2005, p. 102).

Depois de analisar a evolução do mercado de máquinas e equipamentos para o setor canavieiro pela demanda, identificando os principais clientes da Dedini, vamos estudar a evolução da estrutura desse mercado, ou seja, seus principais concorrentes.

O setor de máquinas e equipamentos ligado ao setor canavieiro é relativamente antigo no Brasil, com sua origem no período colonial, mas nesse período não teve desenvolvimento contínuo e permanente. No século XIX, duas empresas destacaram-se na produção de equipamentos para o setor canavieiro: a Fundição do Brasil, no Recife, em Pernambuco, e a Usina Esperança, em Minas Gerais. Ambas as empresas prestavam serviços ou produziam equipamentos simples para atender engenhos, mas também outros ramos de ativida- 
des, além do setor canavieiro. A Usina Esperança, por exemplo, fabricava tubos para encanamentos de água, balaustres e máquinas para engenhos para os mercados do Rio, de São Paulo e do Rio Grande do Sul (Negri, 1977, p. 46-47).

Nas duas primeiras décadas do século XX, outras empresas começaram a atender à demanda por equipamentos e serviços dos vários engenhos do país. No Estado de São Paulo, duas empresas foram premiadas na categoria de máquinas para o setor canavieiro na Exposição Internacional do Centenário da Independência em 1922, no Rio de Janeiro. A Cia. Industrial "Engenho Stamato" ganhou o grande prêmio com seu engenho de ferro para cana, e a Martins Barros e Cia.Ltda. foi premiada pela sua moenda para cana. A premiação no Centenário da Independência representava o que de melhor se produziu no Estado de São Paulo no segmento industrial nos anos 1920.

Tabela 3_Vendas realizadas pelas empresas do grupo Dedini e importações brasileiras de máquinas, aparelhos, utensílios e acessórios para fabricação de açúcar e álcool, 1947-1958 (em mil cruzeiros, a preços constantes de 1965/67)

\begin{tabular}{r|r|r|r|r|r} 
Ano & \multicolumn{1}{l}{$\begin{array}{l}\text { Metalúrgica } \\
\text { Dedini }\end{array}$} & Mausa & Codistil & \multicolumn{1}{l}{$\begin{array}{l}\text { Grupo } \\
\text { Dedini }\end{array}$} & Importações \\
\hline 1947 & 4.888 & \multicolumn{1}{c|}{-} & 588 & 5.474 & 11.912 \\
\hline 1948 & 5.859 & 425 & 552 & 6.837 & 8.153 \\
\hline 1949 & 7.060 & 1.147 & 1.069 & 9.276 & 5.534 \\
\hline 1950 & 9.987 & 2.085 & 1.470 & 13.542 & 5.250 \\
\hline 1951 & 13.150 & 2.817 & 2.146 & 18.111 & 9.330 \\
\hline 1952 & 17.439 & 3.758 & 2.324 & 28.521 & 9.131 \\
\hline 1953 & 11.136 & 2.329 & 1.368 & 14.833 & 3.305 \\
\hline 1954 & 10.194 & 2.273 & 1.905 & 14.372 & 297 \\
\hline 1955 & 9.227 & 2.288 & 1.746 & 13.262 & 84 \\
\hline 1956 & 8.381 & 2.650 & 1.106 & 12.137 & - \\
\hline 1957 & 11.879 & 3.394 & 2.638 & 17.910 & - \\
\hline 1958 & 11.204 & 3.002 & 3.283 & .17 .488 & $\ldots$. \\
\hline
\end{tabular}

Fonte: Negri (1977, p. 63, 67).
Ao longo dos anos 1920, outras empresas produziram equipamentos para o setor canavieiro em São Paulo. Algumas das empresas importantes desse período foram a própria Dedini, a Martins Barros, da cidade de São Paulo, a Carlos Tonanni, de Jaboticabal, e a Krähenbühl, de Piracicaba. Essas empresas fabricavam geralmente pequenas moendas para cana, sendo que a Tonanni produzia centrífugas para engenhos turbinadores. A Krähenbühn foi fundada em 1870 por suíços e inicialmente atendia à demanda de importação e reparos mecânicos da região de Piracicaba. A empresa saiu do mercado de equipamentos e vendeu seu maquinário para a Dedini, em 1940, concentrando-se apenas na comercialização dos produtos agrícolas. A Martins Barros teve sérios problemas econômicos com a Crise de 1929, paralisando suas atividades no período e saindo definitivamente do mercado, nos anos 1940. Essa empresa também vendeu seu maquinário para a Dedini. A Tonanni concentrou sua produção no setor de máquinas para beneficiamento de arroz e café.

Conseguimos catalogar 20 empresas que produziam máquinas para o setor canavieiro no Estado de São Paulo em 1930. A Tabela 4 apresenta essas empresas, com as respectivas cidades, capital e produtos. Algumas delas fabricavam também máquinas para outros setores da agricultura e indústria, como, por exemplo, máquinas para beneficiamento de café, arroz, bombas para serrarias, panificação e aproveitaram para ampliar sua produção para o setor canavieiro.

A indústria de máquinas para o setor canavieiro é baseada em demanda sob encomenda, em sua maior parte de equipamentos fabricados especialmente para determinado engenho ou usina. Mesmo os produtos padronizados nesse setor precisam ser ajustados a cada unidade de produção específica. Os produtos são heterogêneos, em sua maioria, com uma linha relativamente diversificada. A demanda do setor de máquinas para o setor canavieiro está diretamente ligada às condições de mercado para os produtos extraídos pelo 
setor, ou seja, depende dos preços do açúcar e do álcool. As empresas produtoras de máquinas e equipamentos sob encomenda para o setor ficam vinculadas ao setor comprador de seus produtos. Na tentativa de diminuir a dependência de um único setor consumidor dos produtos, as empresas procuram diversificar a linha de máquinas e equipamentos. Neste caso, a base produtiva principal permite flexibilidade na produção, ou equipamentos que se complementam são produzidos por meio de diversas tecnologias. A estratégia de produzir produtos complementares tem como objetivo diminuir as oscilações do mercado. A forma de diversificação mais fácil para diminuir a dependência cíclica de um mercado é através da fabricação de produtos próximos à atividade principal (Negri, 1981, p. 89-93).

Assim, conforme a Tabela 4, vários produtores de máquinas e equipamentos fabricavam equipamentos para uma indústria mais importante (neste caso, o setor canavieiro) e também para outros setores, com características distintas. Interessante notar é a existência de empresas relativamente grandes, com empresas de menor porte, ou seja, há um complemento da produção entre empresas com características diferentes. As empresas menores complementam a produção das maiores fornecendo peças de reposição ou a produção de equipamentos de pequeno porte.

Uma característica importante é que a maioria das empresas de máquinas para o setor canavieiro atendia aos engenhos. A única empresa especializada no fornecimento de máquinas para as usinas, uma unidade de produção mais complexa do que os engenhos, era a Dedini, em 1930. Esse seria um dos fatores que levaria a Dedini a ser líder da indústria produtora de equipamentos para o setor açucareiro. As empresas, que atendiam ao setor, no início dos anos 1930, ofertavam serviços e equipamentos para o mercado de engenhos de açúcar, com tecnologia relativamente simples. $\mathrm{Na}$ década de 1930, com o incentivo do Instituto do Açúcar e Ál- cool, muitos dos engenhos transformaram-se em usinas, grandes unidades de produção de açúcar. Assim, no início dos anos 1930, surgiu o segmento de mercado especializado, substituindo a produção de equipamentos de engenhos para usinas. Enquanto as empresas concorrentes da Dedini produziam equipamentos para o mercado decadente de engenhos de açúcar, a Dedini estava entre as poucas empresas capazes de fornecer máquinas e equipamentos para atender a um mercado em expansão.

Até a década de 1960, a Dedini permaneceu como líder em um segmento de mercado com estrutura próxima a um oligopólio: máquinas para a indústria do açúcar. Outro segmento de mercado no qual a Dedini foi pioneira foi o de máquinas para a produção de álcool, com a constituição da Codistil. As empresas do grupo Dedini (Metalúrgica, Codistil e Mausa) tiveram valor de vendas três vezes maior do que todas as importações brasileiras de máquinas e equipamentos para a fabricação de açúcar e álcool em 1952 (ver Tabela 3). A partir de 1949, as vendas do grupo Dedini foram maiores do que as importações de máquinas para o setor.

A cidade de Piracicaba apresentava-se como um dos principais centros de produção açucareira do Brasil, nos anos 1960. Uma das características das máquinas e dos equipamentos por encomenda é a especificação técnica do comprador. Os compradores, as usinas e os engenhos, neste caso, esperam que os fornecedores de máquinas e equipamentos sejam capazes de atender às demandas das unidades industriais para reposição em curto prazo de entrega e oferecimento de assistência técnica para reparos. Essa característica explica em parte por que as principais empresas de máquinas e equipamentos para a indústria da cana estavam concentradas na região de Piracicaba em 1963 (ver Tabela 5). Embora a Cia. Federal de Fundição e a Bardella produzissem instalações completas para usinas de açúcar, as empresas do grupo Dedini eram especialistas no forne- 
Tabela 4_Empresas produtoras de máquinas e equipamentos para o setor canavieiro, Estado de São Paulo, 1930

\begin{tabular}{|c|c|c|c|}
\hline Empresa & Cidade & Capital (mil-réis) & Produtos \\
\hline Adolpho Bianchi & Ribeirão Preto & 40.000 & engenhos de cana, rodas d’água e reparos máquinas em geral \\
\hline Affonso Ramasco & Campinas & 110.000 & engenhos de cana, máquinas de fazer telhas \\
\hline Angelo Milanesi \& Irmãos & Botucatu & 17.000 & moendas para cana, máquinas para beneficiar café, arroz \\
\hline Antonio Luciano & São Paulo & 60.000 & máquinas para beneficiar café e para moer e picar cana \\
\hline Bruno Meyer \& Filhos & Rio Claro & 60.000 & engenhos para cana, prensas para telhas, peças fundição \\
\hline Cia. Mac-Hardy & Campinas & 943.400 & engenhos para cana, máquinas para beneficiar café \\
\hline Comp. Ind. Stamato & São Paulo & 400.000 & engenhos para moagem de cana, aparelhos para fabricar açúcar \\
\hline Irmãos Colombini & Bauru & 10.000 & engenhos para cana, bombas \\
\hline Irmãos Gazzola & Itu & 28.150 & moendas de cana, artigos de ferro fundido \\
\hline Irmãos Masiero & Jaú & 67.850 & máquinas para beneficiar café e para picar cana, bombas \\
\hline José Bisordi & São Paulo & 80.000 & prensas, moendas e serras \\
\hline Luiz Cestari & Monte Alto & 286.641 & engenhos para cana \\
\hline Raphael Stamato & São Paulo & 200.000 & engenhos de ferro para lavoura de cana \\
\hline V. Lilla & São Paulo & 20.000 & torradores e moinhos de café e engenhos de cana \\
\hline Celeste Toriatti & Socorro & 8.500 & construção de engenhos de cana \\
\hline M. Dedini & Piracicaba & 200.000 & moendas de cana, máquinas para usinas de açúcar \\
\hline Roque Bianchi Filhos Ltda. & Ribeirão Preto & 18.000 & engenhos para moagem de cana \\
\hline Vettorazzo \& Rosa & Sorocaba & 60.000 & máquinas para panificação, serrarias, e engenhos de cana \\
\hline José Gambale & São Paulo & 15.000 & construção de engenhos de cana \\
\hline Frederico Ruegger \& Filhos & Araras & 255.000 & moendas, rodas hidráulicas, prensas, polias \\
\hline
\end{tabular}

Fonte: DEIC/ SAIC/ SP. Estatística Industrial do Estado de São Paulo, 1930.

cimento de máquinas e equipamentos para açúcar e álcool e exerceram forte influência na evolução das empresas da região de Piracicaba.

Instalada em 1936, em Piracicaba, pelo francês Jean Joseph Morlet, a empresa Morlet concorreu, na década de 1940, com a Codistil, na fabricação de destilarias. Entretanto, a Morlet foi adquirida pelo grupo Dedini, em 1958, e incorporada à Codistil, em 1969. A Mepir - Metalúrgica Piracicabana, fundada em 1950, em Piracicaba, foi adquirida pelo grupo Dedini em 1969.

O grupo Dedini disseminou uma forma de "convergência tecnológica" por meio do conhecimento técnico de seus ex-funcionários, que saíram da empresa para fundar as próprias companhias. Segundo Barjas Negri, grande parte das empresas de máquinas para o setor canavieiro de Piracicaba foi instalada pelos ex-operários e técnicos 
Tabela 5_Principais empresas produtoras de máquinas para 0 setor canavieiro, 1963

\begin{tabular}{|c|c|c|}
\hline Empresa & Local & Fundação \\
\hline Cia. Federal de Fundição & Rio de Janeiro-RJ & 1901 \\
\hline Bardella S.A. - Ind. Mecânicas & São Paulo-SP & 1911 \\
\hline Lilla de Máquinas Ind. e Com. & São Paulo-SP & 1918 \\
\hline M. Dedini S.A. - Metalúrgica & Piracicaba-SP & 1920 \\
\hline Morlet - Equip. usinas açúcar e álcool & Piracicaba-SP & 1936 \\
\hline Codistil - Construtora destilaria Dedini & Piracicaba-SP & 1943 \\
\hline Mausa S.A. - Equip. usinas de açúcar & Piracicaba-SP & 1948 \\
\hline Santin S.A. - Indústria metalúrgica & Piracicaba-SP & 1948 \\
\hline Mepir - Metalúrgica Piracicabana S.A. & Piracicaba-SP & 1950 \\
\hline Zanini S.A. - Equipamentos pesados & Sertãozinho-SP & 1950 \\
\hline Fundição Goytacaz S.A. & Campos-RJ & 1953 \\
\hline Mescli - Metalúrgica Santa Cruz S.A. & Piracicaba-SP & 1953 \\
\hline Fazanaro S.A. - Industrial e Comercial & Piracicaba-SP & 1954 \\
\hline Conservit S.A. - Fábricas de caldeiras & São Paulo-SP & 1955 \\
\hline Mario Mantoni Metalúrgica Ltda. & Piracicaba-SP & 1956 \\
\hline Cimei - Cia. Metalúrgica de Equip. & Araras-SP & 1959 \\
\hline Metalúrgica Conger S.A. & Piracicaba-SP & 1962 \\
\hline
\end{tabular}

Fonte: Banas, 1963, p. 43; Negri, 1981, p. 94.

Nota: A Morlet foi adquirida pelo grupo Dedini em 1958 e incorporada à Codistil em 1969. A Mepir foi incorporada ao grupo Dedini em 1969.

das empresas de Mário Dedini. Esses funcionários assimilaram os processos de produção de vários equipamentos para o setor. Assim, outras empresas mecânicas desenvolveram-se em Piracicaba por influência da Dedini. Tais empreendimentos eram basicamente pequenas e médias oficinas que forneciam peças e equipamentos não produzidas pelas grandes empresas.

Assim, essas pequenas e médias empresas complementavam a produção da Dedini no atendimento às usinas. Duas empresas que surgiram dessas condições foram a Santin S.A.
Indústria Metalúrgica, em 1948, e a Mario Mantoni Metalúrgica Ltda., em 1956 (Negri, 1981, p. 95; Leão, 2005, p. 109-110). A oferta de mão de obra especializada atraiu investimentos de outros setores para a cidade de Piracicaba. Portanto, a economia canavieira foi responsável direta e indiretamente pelo estabelecimento de grande número de empresas na cidade de Piracicaba, ligadas aos encadeamentos do setor.

No início da década de 1960, a indústria de máquinas para o setor canavieiro era autossuficiente, produzindo todos os equipamentos necessários para o setor de açúcar e álcool. As empresas do grupo Dedini, além de produzir todos os equipamentos necessários às usinas e às destilarias do país, realizaram exportações de seus equipamentos para a América Latina, especialmente para a Argentina, a Bolívia e o Uruguai (Banas, 1963, p. 43).

\section{2_0 mercado de máquinas operatrizes e a Romi}

Depois de analisar a evolução do mercado de máquinas para o setor canavieiro, no qual a Dedini está inserida, vamos considerar o mercado de máquinas operatrizes o principal mercado da Romi. As máquinas operatrizes estão inseridas na classificação do gênero industrial mecânica e têm como finalidade produzir novas máquinas por meio do movimento mecânico, de um conjunto de ferramentas. São classificados como máquinas operatrizes os tornos, as retificadoras, as rosqueadoras, as plainas, as fresadoras, as mandriladoras, as furadeiras, as serras, as tesouras, as prensas, e outras. $\mathrm{O}$ torno é uma das mais antigas máquinas inventadas pelo homem e tem como objetivo cortar, limar ou polir peças de madeira, metal ou outro material. Como existem diversos tipos, o torno pode ser utilizado por uma pequena oficina mecânica ou em uma complexa organização industrial.

Como vimos anteriormente, a Romi iniciou suas atividades produzindo máquinas agrícolas e, em 1941, iniciou a produção de tornos. A indústria de máquinas operatrizes é 
constituída no Brasil, com empresas produzindo de forma contínua esse tipo de máquina, na década de 1930. Entretanto, antes desse período, algumas empresas produziam algumas máquinas para uso próprio.

Édifícil identificar os clientes da Romi ao longo dos anos. Podemos, porém, fazer algumas generalizações para entender melhor as características do mercado de tornos no país, entre 1940 e 1960. Os principais clientes foram as indústrias de autopeças, a de ferramentaria (que usam o torno na produção de máquinas) e o setor de manutenção (como o setor de vidro, cimento ou porcelana, que usam o torno mais simples, na manutenção). Assim, a produção de tornos da Romi deuse tanto em série, para atender clientes que exigem menor complexidade do torno, como também sob encomenda, para atender a finalidades específicas. $\mathrm{O}$ mercado atendido pela Romi nesse período foi de clientes diversificados, que exigiam relativo grau de complexidade tecnológica nos produtos produzidos pela empresa (Banas, 1970, p. 7-12).

Não existem informações estatísticas detalhadas para estimar a produção de tornos no país e sua respectiva demanda no período aqui abordado. As estatísticas de comércio exterior também não detalham a quantidade e o valor dos tornos importados. O maior nível de detalhe disponível é para a importação de máquinas operatrizes pelo Brasil e por São Paulo, pelo porto de Santos. Esses dados entre 1938 e 1943 são apresentados na Tabela 6 . Tal período é importante porque abrange o período de projeto e início da produção de tornos pela Romi, motivada pela dificuldade de importação em uma época de guerra e necessidade dessas máquinas pelo parque industrial paulista e brasileiro.

Pela análise da Tabela 6, é possível perceber a oscilação da importação de máquinas operatrizes pelo Estado de São Paulo, pelo porto de Santos, e pelo Brasil, entre 1938 e 1943. A Segunda Guerra Mundial ajudou a diminuir as importações das máquinas operatrizes, pelo menos entre 1938 e 1941, em São Paulo. Em 1942, houve pequena recuperação das importações em quantidade em São Paulo, possivelmente por causa da necessidade de renovação das máquinas do maior parque industrial do país. O interessante é que o movimento de recuperação das importações de máquinas operatrizes pelo

Tabela 6_Importação de máquinas operatrizes pelo Estado de São Paulo e pelo Brasil, 1938-1943 (toneladas e mil cruzeiros correntes)

\begin{tabular}{|c|c|c|c|c|c|c|}
\hline Ano & $\begin{array}{l}\text { São Paulo (Porto de Sa } \\
\text { Quantidade } \\
\text { (toneladas) }\end{array}$ & $\begin{array}{l}\text { antos) } \\
\text { Valor } \\
\text { (mil cruzeiros) }\end{array}$ & $\begin{array}{l}\text { Brasil } \\
\text { Quantidade } \\
\text { (toneladas) }\end{array}$ & $\begin{array}{l}\text { Valor } \\
\text { (mil cruzeiros] }\end{array}$ & $\begin{array}{l}\text { \% quantidade } \\
\text { São Paulo }\end{array}$ & $\begin{array}{l}\text { \% valor } \\
\text { São Paulo }\end{array}$ \\
\hline 1938 & 377 & 6.675 & 1.079 & 17.674 & 34,98 & 37,77 \\
\hline 1939 & 286 & 4.726 & 757 & 13.709 & 37,83 & 34,47 \\
\hline 1940 & 277 & 4.885 & 511 & 10.199 & 54,25 & 47,90 \\
\hline 1941 & 246 & 3.967 & 1.350 & 36.645 & 18,25 & 10,82 \\
\hline 1942 & 252 & 7.855 & 911 & 23.949 & 27,66 & 32,80 \\
\hline 1943 & 215 & 3.996 & 1.762 & 55.737 & 12,22 & 7,17 \\
\hline
\end{tabular}

Fonte: DEIC/ SAIC/ SP. Estatística do Comércio do Porto de Santos com os países estrangeiros, 1938 - 1943; Brasil. Conselho Federal de Comércio Exterior. Comércio exterior do Brasil: Importação e exportação segundo a utilização e o grau de elaboração dos produtos, 1938-1943. Rio de Janeiro: Imprensa Nacional, 1945. Nota: Máquinas operatrizes são tornos, retificadoras, rosqueadoras, plainas, fresadoras, mandriladoras, furadeiras, serras, tesouras, prensas, e outras máquinas não especificadas. 
Brasil, a partir 1941, não foi acompanhado pelas importações do Estado de São Paulo. A participação relativa desse Estado no total das importações de máquinas operatrizes do país aumentou entre 1938 e 1940 (de 35\% para 54\% da quantidade relativa de máquinas importadas pelo país e de $37 \%$ para $48 \%$ do valor das máquinas importadas do país, ver Tabela 6), mas caiu para 12\% da quantidade e $7 \%$ do valor das importações de máquinas operatrizes do país, em 1943. Essa é uma evidência de substituição de importação em máquinas operatrizes pelo parque industrial paulista, o mais dinâmico do Brasil, entre 1941 e 1943, explicado possivelmente pelo aumento da produção interna do período.

Outras informações dão evidências de substituição de importação de máquinas operatrizes pelo Estado de São Paulo no início dos anos 1940. A Tabela 7 mostra as empresas produtoras de tornos nesse Estado, em 1945. Percebemos um número substancial de empresas iniciando suas atividades a partir de 1940, apesar de a data de fundação na tabela indicar a última alteração na razão social da empresa. Das 45 empresas que conseguimos identificar produzindo tornos no Estado de São Paulo em 1945, 31 foram fundadas a partir de 1940.

Entretanto, tais empresas foram importantes ao ponto de produzirem uma quantidade de tornos que afetou as importações de máquinas operatrizes do Estado de São Paulo? Como é possível perceber pela mesma tabela, havia grande heterogeneidade entre as empresas que produziam tornos no período. A maioria das empresas fundadas após 1940 apresentava tamanho, medido pelo número de operários e capital, muito menor do que as anteriores. Essas empresas aproveitaram as dificuldades na importação de máquinas operatrizes, condições especiais no comércio exterior dadas pela Segunda Guerra Mundial, para ingressar em um mercado com demanda crescente. As barreiras à entrada não eram altas. $\mathrm{O}$ capital e a quantidade de operários necessários para a produção de tornos eram relativamente baixos.
A tecnologia para a produção era absorvida pelo meio de cópia de tornos importados.

A facilidade de entrada no mercado de máquinas-ferramenta em construção resultou em características muito diferentes das empresas do setor. A maioria das empresas fundadas no início dos anos 1940 não conseguiu se manter no mercado. Uma empresa importante para a substituição de importações de tornos no início dos anos 1940 foi a Máquinas Agrícolas Romi Ltda. A Tabela 8 apresenta informações referentes a valores e quantidades de tornos produzidos pela Romi e a participação relativa para o mercado interno e externo entre 1941, início de sua produção, até 1958.

A tabela mostra que, de 1941 até 1947, a produção de tornos pela Romi foi crescente. Os primeiros tornos foram produzidos com adaptação, improviso e invenção. Para produzir os barramentos do torno, era necessária uma plaina de mesa de grande porte. Como existiam poucos desses equipamentos no país, e a importação era dificultada pela guerra, a plaina foi construída pela própria empresa parcialmente de madeira. ${ }^{4}$ Durante a guerra, a Romi explorou ao máximo sua capacidade de produção. Em 1942, a produção era realizada em três turnos, racionalizando o processo de produção. Várias mudanças foram necessárias no processo produtivo e administrativo da empresa, no início dos anos 1940. Em 1943, foi construída uma nova fábrica, mais adequada para a produção de tornos. A produção em série era de tornos mecânicos paralelos de um metro e meio entre pontas, isto é, um torno relativamente simples, mas o comumente usado no país.

O mercado interno para os tornos com essas características não foi suficiente, e a Romi começou a exportar em 1944, primeiramente para a Argentina, depois para outros países da América Latina, e, antes de terminar a década de 1940, a exportação foi estendida para outros continentes. As exportações foram importantes para a Romi, entre 1945 e 1949, chegando a representar $45 \%$ da quantidade produzida pela 
Tabela 7_Empresas produtoras de tornos, Estado de São Paulo, 1945

\begin{tabular}{|c|c|c|c|c|}
\hline Empresa & Fundação & Capital & Operários & Produtos \\
\hline Carlos Tonanni \& Cia. Ltda. & 1902 & 1.191 .913 & 128 & tornos para máquinas plainas \\
\hline Bromberg \& Cia. & 1920 & 2.614.198 & 121 & tornos e reconstrução máquinas \\
\hline Fábrica de Máquinas Frig. Niper Ltda. & 1923 & 536.359 & 18 & fresas, tornos mecânicos \\
\hline Artur Bosetti & 1926 & 211.160 & 47 & bombas e tornos para bancadas \\
\hline José de La Rosa & 1931 & 50.000 & 12 & tornos e prensas \\
\hline Ângelo Marzonchi & 1934 & 10.000 & 3 & plainas e tornos \\
\hline Oficina Mecânica Bruno Corradini & 1935 & 144.360 & 4 & plainas e tornos mecânicos \\
\hline De Lorenzi S.A. & 1935 & 752.834 & 13 & turbinas hidráulicas e tornos \\
\hline Irmãos Vesibelle & 1937 & 406.862 & 23 & tornos mecânicos e serviços \\
\hline José Pacubi & 1937 & 30.000 & - & tornos mecânicos \\
\hline Alnorma de Máquinas S.A. & 1938 & 11.096 .136 & 172 & tornos e mandrileiras \\
\hline Otto Gruendel & 1938 & 420.987 & 7 & torno, revólver e acessórios \\
\hline Máquinas Agrícolas Romi Ltda. & 1938 & 2.960 .337 & 526 & tornos mecânicos, arados \\
\hline A. Mintz & 1940 & 15.000 & 5 & tornos e plainas mecânicas \\
\hline Barsotti \& Venturelli & 1940 & 151.748 & 13 & tornos mecânicos \\
\hline Irmãos Amodio Ltda. & 1940 & 195.169 & 3 & tornos mecânicos e consertos \\
\hline Mecânica Nacional S.A. & 1940 & 4.193.924 & 155 & tornos mecânicos e betoneiras \\
\hline Viúva Herrero & 1940 & 364.622 & 67 & tornos mecânicos \\
\hline Felicio João Macella & 1941 & 50.300 & 7 & tornos mecânicos e reformas \\
\hline Prema Máquinas de Precisão Ltda. & 1941 & 186.320 & 7 & tornos e fresas \\
\hline Soc. Máquinas Indústria e Lavoura & 1941 & 182.597 & 14 & tornos mecânicos e engenhos \\
\hline Anastácio Ventura \& Cia. Ltda. & 1942 & 155.000 & 5 & tornos mecânicos \\
\hline Giordano Bianco & 1942 & 22.000 & - & tornos mecânicos \\
\hline Jorge Franco \& Cia. & 1942 & 226.217 & 4 & tornos mecânicos \\
\hline Manuel Alonso & 1942 & 61.000 & 7 & tornos mecânicos \\
\hline Manuel Herrero & 1942 & 704.903 & 24 & tornos mecânicos \\
\hline Máquinas Bianco Ltda. & 1942 & 162.701 & 4 & tornos mecânicos \\
\hline Nagrib Maia \& Cia. Ltda. & 1942 & 2.058 .135 & 81 & tornos mecânicos \\
\hline Pedro Cantele & 1942 & 544.000 & 17 & tornos mecânicos \\
\hline Soc. Mecânica Vera Cruz Ltda. & 1942 & 524.522 & 46 & tornos e furadeiras \\
\hline
\end{tabular}




\begin{tabular}{|c|c|c|c|c|}
\hline Empresa & Fundação & Capital & Operários & Produtos \\
\hline J. Sanches Blanes \& Irmãos & 1943 & 18.000 & - & tornos e consertos \\
\hline Kato \& Cia. & 1943 & 12.000 & 5 & tornos mecânicos \\
\hline Mecânica Parc Ltda. & 1943 & 220.140 & 3 & tornos mecânicos \\
\hline Oficina Mecânica E. T. D. Ltda. & 1943 & 149.500 & 8 & tornos e consertos \\
\hline R. Silva \& Garcia & 1943 & 88.347 & 4 & tornos mecânicos e peças \\
\hline Soc. Electro Mecânica Somar Ltda. & 1943 & 383.540 & 40 & tornos mecânicos \\
\hline Técnica Industrial Mecânica Ltda. & 1943 & 203.063 & 7 & fresas, tornos e consertos \\
\hline Mecânica Universal Ltda. & 1943 & 182.299 & 9 & tornos mecânicos e acessórios \\
\hline Indústria e Com. de Máquinas ICM & 1944 & 250.592 & 6 & tornos mecânicos \\
\hline Indústria Mecânica Vitor Ltda. & 1944 & 349.339 & 9 & tornos e prensas \\
\hline Máquinas Independência Ltda. & 1944 & 108.000 & 7 & tornos e cilindros \\
\hline Máquinas Labor Ltda. & 1944 & 42.000 & 3 & tornos, bases e outras máquinas \\
\hline Mecânica Imã Ltda. & 1944 & 63.423 & 5 & tornos mecânicos \\
\hline Shunzo Ikemori & 1944 & 70.000 & 2 & máquinas para furar, tornos \\
\hline Oficina Mecânica Gal. Osório & & 209.500 & 15 & tornos \\
\hline
\end{tabular}

Fonte: DEE/DEPC/SP. Catálogo das Indústrias do Estado de São Paulo, município da capital e interior, 1945, São Paulo: Tipografia Brasil, 1947.

Nota: Capital em cruzeiros correntes. Fora da capital do Estado de São Paulo informações qualitativas indicam que a Nardini produziu tornos em 1945. Os dados dessa empresa são os seguintes: Indústria de Máquinas Agrícolas Nardini Ltda., capital de 1.168.114, com 100 operários, produzindo máquinas para a agricultura. As únicas firmas produtoras de tornos fora da capital do Estado foram a Romi, em Santa Bárbara, a Tonanni, em Jaboticabal, e a Mecânica Universal, em Santo André. As datas de fundação na tabela indicam a última alteração na razão social da empresa.

empresa em 1947, que voltaria a exportar tornos em grandes quantidades apenas na década de 1960.

Em 1946, a Romi renovou seu maquinário em um leilão de máquinas-ferramenta, excedentes de guerra dos Estados Unidos, em Petterson, Nova Jersey. Esse investimento foi muito vantajoso para a empresa porque ampliou sua capacidade de produção a um custo relativamente baixo. Esses equipamentos permitiram o primeiro salto tecnológico da empresa, constituindo o plano de expansão entre 1946 e 1952. A ampliação do maquinário foi realizada em um período de aumento da concorrência no mercado de máquinas no mundo, principalmente de tornos, com a reconstrução industrial dos países desenvolvidos após a Segunda Guerra Mundial.
De 1948 a 1953, a produção de tornos da Romi diminuiu em razão da concorrência externa. A empresa começou a diversificar a sua produção, fabricando teares mecânicos, os primeiros tratores fabricados no país, bombas hidráulicas, motores e outros. A produção de tornos voltou a crescer com a mudança da política cambial instituída pela Instrução 70 da Superintendência da Moeda e do Crédito (SUMOC) de 1953, que estabeleceu as taxas de câmbio múltiplas e criou sobretaxas para as importações de manufaturados; a implantação da indústria automobilística e a necessidade de aparelhar o setor de autopeças a partir de 1954. O setor de autopeças se estabeleceu inicialmente usando métodos convencionais de produção. A Romi acompanhou a evolução desse mercado, passando 
Tabela 8_Produção total de tornos da Romi e sua respectiva participação para os mercados interno e externo, 1941-1958 (unidades e US\$ correntes]

\begin{tabular}{|c|c|c|c|c|c|c|}
\hline Anos & $\begin{array}{l}\text { Produção total } \\
\text { (unit) }\end{array}$ & $\begin{array}{l}\text { Produção total } \\
\text { (US\$) }\end{array}$ & $\begin{array}{l}\text { \% produção mercado } \\
\text { interno (unit) }\end{array}$ & $\begin{array}{l}\text { \% produção mercado } \\
\text { interno (US\$) }\end{array}$ & $\begin{array}{l}\text { \% produção exportação } \\
\text { [unit] }\end{array}$ & $\begin{array}{l}\text { \% produção exportação } \\
\text { [US\$] }\end{array}$ \\
\hline 1941 & 46 & 24.029 & 100,0 & 100,0 & 0,0 & 0,0 \\
\hline 1942 & 193 & 101.902 & 100,0 & 100,0 & 0,0 & 0,0 \\
\hline 1943 & 770 & 521.610 & 100,0 & 100,0 & 0,0 & 0,0 \\
\hline 1944 & 899 & 739.109 & 99,1 & 99,1 & 0,9 & 0,9 \\
\hline 1945 & 1.098 & 797.250 & 90,5 & 90,4 & 9,5 & 9,6 \\
\hline 1946 & 1.660 & 1.147 .990 & 69,0 & 81,7 & 14,8 & 18,3 \\
\hline 1947 & 1.110 & 1.015 .294 & 55,0 & 56,1 & 45,0 & 43,9 \\
\hline 1948 & 731 & 897.807 & 60,2 & 66,9 & 39,8 & 33,1 \\
\hline 1949 & 798 & 871.711 & 78,9 & 80,9 & 21,1 & 19,1 \\
\hline 1950 & 857 & 1.540 .663 & 100,0 & 100,0 & 0,0 & 0,0 \\
\hline 1951 & 1.379 & 2.383.155 & 100,0 & 100,0 & 0,0 & 0,0 \\
\hline 1952 & 942 & 2.091 .711 & 99,6 & 99,6 & 0,4 & 0,4 \\
\hline 1953 & 880 & 1.067.229 & 99,5 & 99,4 & 0,5 & 0,6 \\
\hline 1954 & 1.306 & 1.568 .483 & 100,0 & 100,0 & 0,0 & 0,0 \\
\hline 1955 & 1.492 & 1.764 .560 & 100,0 & 100,0 & 0,0 & 0,0 \\
\hline 1956 & 1.629 & 2.807 .718 & 98,0 & 96,7 & 2,0 & 3,3 \\
\hline 1957 & 1.449 & 2.668.022 & 99,8 & 99,6 & 0,2 & 0,4 \\
\hline 1958 & 1.779 & 2.398.312 & 99,8 & 99,9 & 0,1 & 0,1 \\
\hline
\end{tabular}

Fonte: Romi. Centro de Documentação Histórica Romi.

a fornecer máquinas e equipamentos mais desenvolvidos, conforme a necessidade das empresas, como o torno pesado Imor modelo TP-100, produzido em 1960. Até esse ano, a empresa havia produzido 22 mil tornos e exportado 1.380. Na década de 1960, a Romi tornou-se uma das maiores produtoras de tornos do mundo, ficando atrás apenas de uma empresa estatal da União Soviética, exportando para 41 países, inclusive para países desenvolvidos, como os Estados Unidos (Brandão, 2008; Banas, 1970; Exame, 1973).

\section{5_Conclusões}

Este artigo apresentou a evolução histórica desde a origem dos dois empresários, Dedini e Romi e de suas empresas de máquinas e equipamentos no Estado de São Paulo, até os anos 1960, identificando semelhanças e diferenças que compartilharam. Em ambos os casos, notamos a origem familiar italiana, conhecimentos e habilidades na área de mecânica e alguma ligação com o setor agrícola. Os dois empresários percorreram a mesma região geográfica do interior de São Paulo, apesar de momentos diferentes. Uma hipótese advém 
do fato de que as fazendas agrícolas (de café, cana-de-açúcar) da região Nordeste e Central do Estado de São Paulo atraíram imigrantes que possuíam outras habilidades, além do trabalho na lavoura. Essa atração pode ser explicada pela existência de estradas de ferro na região e das fazendas de engenho e de café, que demandavam manutenção para seus equipamentos (locomotivas, vagões, máquinas de beneficiamento agrícola, caldeiras e moendas de cana-de-açúcar, carroças, automóveis e outros implementos agrícolas).

O início da produção de máquinas e equipamentos no interior de São Paulo esteve ligado ao processo de desenvolvimento econômico local ou regional. O processo de desenvolvimento econômico de Piracicaba e de Santa Bárbara, no início do século XX, local de instalação da oficina Dedini e da Romi, é um exemplo dessa interligação entre a agricultura local e o crescimento e desenvolvimento da indústria. As atividades agroindustriais locais viabilizaram o aparecimento de empresas para atender à demanda de máquinas do setor.

$\mathrm{Na}$ década de 1940, as estratégias de desenvolvimento da Dedini e da Romi tomaram rumos diferentes. Durante a Segunda Guerra Mundial, com a interrupção das importações, a Romi decidiu especializar a sua produção e produzir um novo produto, o torno. A Dedini notou a necessidade de complementar os produtos que fabricava para as usinas e aprofundou o processo de diversificação de seus produtos, fundando novas firmas para a produção de máquinas e equipamentos destinados ao setor alcooleiro e máquinas especializadas para o setor açucareiro. A Dedini aprofundou sua atuação no mercado de máquinas agrícolas específico para o setor canavieiro, primeiramente produzindo máquinas para as usinas de açúcar e depois para destilarias de aguardente e álcool. A Romi, após atingir o sucesso no ramo de máquinas agrícolas para a o cultivo da terra como arados, semeadeiras e outros, ampliou sua produção para máquinas voltadas para a indústria, sendo a mais universal dessas máquinas o torno mecânico. A Dedini e a Romi continuam presentes no mercado de máquinas e equipamentos e são consideradas empresas importantes nos ramos específicos em que atuam.

\section{Notas \\ ${ }^{1}$ A importância da evolução e o desenvolvimento da indústria de máquinas e equipamentos em perspectiva histórica podem ser consultados em Floud (1976), para a Grã-Bretanha; Landes (2005), para o continente europeu; Rosenberg (1963), para os Estados Unidos; e Chudnovsky; Nagao (1983), para países em desenvolvimento. \\ ${ }^{2}$ Para uma narrativa sobre a historiografia, metodologia, exemplos de trabalhos e a evolução da História de Empresas ou Empresarial no Brasil, ver Freitas Filho (1989) e Lobo (1997).}

\author{
${ }^{3} \mathrm{Na}$ Crise de 1929, a política \\ de defesa do café manteve a \\ procura efetiva e o nível de \\ emprego nos outros setores da \\ economia brasileira, ao mesmo \\ tempo em que tendia a agravar \\ o desequilíbrio externo, com \\ desvalorização cambial e \\ elevação dos preços dos artigos \\ importados. A renda criada ficava \\ represada e era direcionada para \\ os produtores internos (Furtado, \\ 2000, cap. 31 e 32). \\ ${ }^{4}$ Um relato dessas histórias de \\ adaptações e inventividade pode \\ ser encontrado em Brandão (2008, \\ p. 58-73) e nos vários documentos \\ disponíveis no Centro de \\ Documentação Histórica da Romi.
}




\section{Fontes primárias}

BANAS, Geraldo. Anuário Banas: Máquinas e ferramentas. São Paulo: Banas, 1963.

BANAS, Geraldo. Quatro mosqueteiros de Santa Bárbara d'Oeste Banas: Semanário industrial e financeiro. 13 de abril, 1970.

BRASIL. Conselho Federal de Comércio Exterior. Comércio exterior do Brasil: Importação e exportação segundo a utilização e o grau de elaboração dos produtos, 1938-1943. Rio de Janeiro: Imprensa Nacional. 1945.

BRASIL. Instituto Brasileiro de Geografia e Estatística. Anuário Estatístico do Brasil, 1948 - 1960.

Rio de Janeiro, vários anos.

CEPAL. La fabricación de maquinarias y equipos industriales em América Latina: Las maquinas-herramientas em el Brasil. Nueva York, 1962.

\section{DEE/DEPC/SP. Catálogo das} indústrias do Estado de São Paulo: Município da capital e interior, 1945. São Paulo: Tipografia Brasil, 1947.

DEIC/SACOP. A lavoura da canna e a industria assucareira dos estados paulista e fluminense, 1912.
DEIC/SAIC/SP. Estatística Industrial do Estado de São Paulo, 1928-1937, 1938-1939.

DEIC/SAIC/SP. Estatística do Comércio do Porto de Santos com Países Estrangeiros, 1928-1933.

DIÁRIO DE SÃO PAULO: Jornal Diário de São Paulo, máquinas agrícolas Romi Limitada. 19/02/1939.

DGE/ MAIC. A industria assucareira no Brazil. Rio de Janeiro. Tipografia de Estatística, 1919.

DGE/ MAIC. Recenseamento do Brasil 1920, vol. V. (primeira parte): indústria. Rio de Janeiro. Tipografia de Estatística, 1927.

EXAME. Os Pioneiros: Emílio Romi: O construtor de máquinas. São Paulo: abril, julho de 1973.

EXAME. Os Pioneiros: Dedini: do açúcar ao átomo. São Paulo: abril, outubro de 1975.

FIBGE. Censos Industrial,

Comercial e de Serviços.

(série regional), vol. XXV, tomo, Estado de São Paulo, Rio de Janeiro, 1955.
O BANDEIRANTE: Jornal O

Bandeirante, pela indústria barbarense, 20/05/1934. Centro de Memória Romi.

ROMI. Arquivos Romi. Catálogo IMOR - Máquinas Agrícolas Romi Ltda. Santa Bárbara do Oeste. São Paulo: Roman, 1970.

ROMI. Arquivos Romi. Recorte "A fábrica da família Romi". Santa Bárbara do Oeste, São Paulo, 1970b.

ROMI. Centro de Documentação Histórica Romi (Arquivos).

Santa Bárbara do Oeste, São Paulo (vários anos).

SANTA BÁRBARA. Jornal Cidade de Santa Bárbara, Officinas Romi, 24/12/1933, A riqueza intangível de $\mathrm{S}$. Bárbara e o dinamismo criador de seu povo, 13/05/1937; In: Centro de Memória Romi.

VISÃO. Torno vai, divisa vem. Revista semanal-11 de agosto de 1961.

\section{Fontes secundárias}

ALLEN, Robert C. The British Industrial Revolution in global perspective: How commerce created the Industrial Revolution and modern economic growth. Working paper Nuffield College. University of Oxford, 2006.

BRANDÃO, Ignácio de Loyola. Oficina de sonhos: Américo Emílio Romi, aventuras de um pioneiro. São Paulo: Editora DBA, 2008.

CHUDNOVSKY, Daniel; NAGAO, Masafumi. Capital goods production in Third World: An economic study of technology acquisition. New York: St Matrin's Press, 1983.

FLOUD, Roderick. The British machine tool industry, 18501914. Cambrigde: Cambridge University Press, 1976.

FREITAS FILHO, Almir Pita. História Econômica e História de Empresa: Algumas reflexões metodológicas. Ensaios FEE, vol. 10, n. 1, 1989 .

FURTADO, Celso. Formação econômica do Brasil. 27. ed. São Paulo: Companhia Editora Nacional, Publifolha, 2000. 
LANDES, David S. Prometeu desacorrentado: Transformações tecnológicas e desenvolvimento industrial na Europa ocidental, de 1750 até os dias de hoje. 2. ed. Rio de Janeiro: Elsevier, 2005.

LEÃo, Regina Machado. Dedini: A força de um ideal. Piracicaba: R. M. Leão, 2005.

LOBO, Eulália L., História Empresarial. In: CARDOSO, Ciro Flamarion; VAINFAS, Ronaldo (Orgs.). Domínios da história: Ensaios de teoria e metodologia. Rio de Janeiro: Campus, 1997.

NEGRI, Barjas. Um estudo de caso da indústria nacional de equipamentos: Análise do grupo Dedini (1920-1975). 1977. 174 f. Dissertação (Mestrado em Ciências Econômicas) Unicamp, Campinas, 1977.

NEGRI, Barjas. A indústria brasileira de equipamentos para o setor produtor de açúcar e álcool: Um estudo de oligopólio. Revista de Economia Política, v. 1, n. 3, jul./set. 1981.

ROSENBERG, Nathan. Capital goods, technology, and economic growth. Oxford

Economic Papers, New Series, Vol. 15, No. 3 (Nov., 1963a), p. $217-227$.

ROSENBERG, Nathan.

Technological change in the machine tool industry, 1840-1910. The Journal of Economic History, Vol. 23, No. 4 (Dec., 1963b),

p. 414-443.
THOMSON, Ross. Eras of technological convergence: Machine tools and mechanization in the United States, 1820-1929. Economic History Association meetings, Sept. 2010.

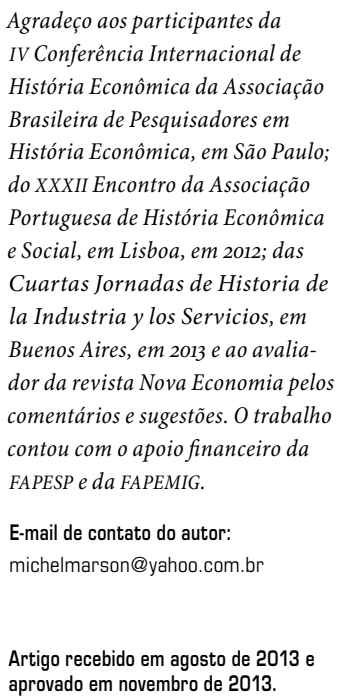

